\title{
Influence of primer mismatch and microdiversity on DGGE results: a case study with SAR11
}

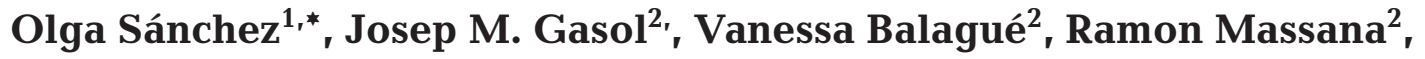 \\ Jordi Mas' ${ }^{1}$, Carlos Pedrós-Alión \\ ${ }^{1}$ Departament de Genètica i Microbiologia, Universitat Autònoma de Barcelona, 08193 Bellaterra, Spain \\ ${ }^{2}$ Departament de Biologia Marina i Oceanografia, Institut de Ciències del Mar CMIMA-CSIC, 08003 Barcelona, Spain
}

\begin{abstract}
Although SAR11 is usually the dominant bacterial group in most marine ecosystems when analyzed with clone libraries and fluorescence in situ hybridization, it is often not retrieved in studies where denaturing gradient gel electrophoresis (DGGE) has been used. We analyzed the microdiversity of SAR11 in Blanes Bay (NW Mediterranean) and we suggest that the high evenness of multiple microdiverse phylotypes, none of which being particularly dominant, is the probable reason for this methodological discrepancy. We used seeding experiments in which different amounts of 2 SAR11-affiliated clones were mixed with DNA from an environmental sample obtained from the Blanes Bay Microbial Observatory. Two primer sets differing at 2 base positions produced DGGE images that varied in their SAR11 detection threshold concentration. Our results show that primer mismatches and/or the presence of faint bands due to microdiversity could explain why SAR11 is frequently not retrieved from DGGE gels.
\end{abstract}

KEY WORDS: DGGE $\cdot$ SAR11 $\cdot$ Microdiversity $\cdot$ Primers $\cdot$ Methodology

Resale or republication not permitted without written consent of the publisher

\section{INTRODUCTION}

Denaturing gradient gel electrophoresis (DGGE) is often used to describe bacterioplankton community structure because it is thought to offer a fair representation of the most abundant groups in natural communities, allowing the comparison of a large number of samples along spatial, temporal or experimental gradients (Riemann et al. 1999, Casamayor et al. 2000, Schauer et al. 2003).

However, the literature abounds with reported discrepancies in microbial assemblage composition found when DGGE results are compared to other molecular techniques such as clone libraries or fluorescence in situ hybridization (FISH) (Castle \& Kirchman 2004, Alonso-Sáez et al. 2007). An example of such discrepancies occurs with SAR11, an alphaproteobacterial clade, which is considered to be the most abundant phylogenetic group in the sea (Morris et al. 2002), often contributing $35 \%$ of total prokaryotes in the sur- face ocean. Members of the SAR11 clade consistently dominate 16S rDNA clone libraries (Bano \& Hollibaugh 2002, Alonso-Sáez et al. 2007, Crump et al. 2007), and usually account for a large proportion of the bacterial assemblage in FISH studies (Morris et al. 2002, Alonso-Sáez et al. 2007). Functional studies also suggest that they are active and play a significant role in carbon, nitrogen, and sulfur cycling in the ocean (Alonso-Sáez \& Gasol 2007, Alonso-Sáez et al. 2008). However, in many studies where DGGE has been used, this bacterial group was not retrieved (e.g. Fandino et al. 2001, Schauer et al. 2003, Pinhassi et al. 2004, Sala et al. 2005, Kan et al. 2006, Alonso-Sáez et al. 2007, Celusi \& Cataletto 2007, Sapp et al. 2007).

Discrepancies between molecular methods have also been found for other bacterial groups (Kong et al. 2001, Castle \& Kirchman 2004). These studies concluded that DGGE could be expected to identify the most abundant phylogenetic groups even if only a few bands were analyzed, unless all representatives of a particu- 
lar phylogenetic group were rare. Other authors have reported difficulties in detecting many rare ribotypes with DGGE because they were yielding many faint, hardly detectable DGGE bands (Torsvik et al. 1998, Kisand \& Wikner 2003).

Substantial microdiversity is one of the factors that could lead to an underestimation of a dominant bacterial group by DGGE. In this case, instead of an intense band of a nondiverse phylotype, different closely related (microdiverse) sequences would share the biomass of the group and none would be dominant in abundance. In a DGGE gel, such a group would appear split in different faint bands, which would escape sequencing efforts. The SAR11 group is known to show a high degree of microdiversity in natural populations (García-Martínez \& Rodríguez-Valera 2000, Acinas et al. 2004), and it could be hypothesized that the different DGGE studies that have failed to detect this abundant clade did so for this reason. Alternatively, it could be hypothesized that lack of detection is due to inappropriate primer choice, with the commonly used primers showing biases against that group.

Here we tested these 2 hypotheses for the SAR11 group in Blanes Bay (NW Mediterranean) samples. This is one of the places where the group is abundant, as clone libraries and catalyzed reporter deposition (CARD)-FISH reveal, but where it has been rarely retrieved using DGGE (Schauer et al. 2003, Alonso-Sáez et al. 2007). We analyzed the level of microdiversity within the group and compared it to other groups abundant at the site. We further tested the effect of small differences in the primers used (357fGC-907r and 357fGC-907rM) on the detectability of variable amounts of SAR11 over a background formed by a natural community. These primer sets have been frequently described in the literature and, in addition, we recently showed that primer set $357 \mathrm{fGC}-907 \mathrm{rM}$ was the most adequate for the routine use of polymerase chain reaction (PCR)-DGGE analyses of bacterioplankton samples among 5 different primer pairs commonly used in molecular microbial ecology studies (Sánchez et al. 2007).

\section{MATERIALS AND METHODS}

Estimation of microdiversity. A subset of sequences of SAR11 (20 clones) and Roseobacter (20 clones), randomly selected from 4 clone libraries from the Blanes Bay Microbial Observatory (described in Alonso-Sáez et al. 2007), were aligned with Clustal X (Thompson et al. 1997) and grouped into similarity clusters using the Clusterer bioinformatics tool (Klepac-Ceraj et al. 2006; http://web.mit.edu/polz/clusterer/). This allows grouping of sequences into percentage similarity clusters (100, $99,98 \%$, and so on) by the neighbor-joining method.
Samples. Two clones (BL03-AUT03 [A3] and BL03SUM03 [S3], accession numbers DQ778230 and DQ77814, respectively) retrieved from two 16S rRNA clone libraries from the Blanes Bay Microbial Observatory were selected. These two clones contained recombinant plasmids with an insert affiliated with the SAR11 cluster and had a similarity value of $95.2 \%$. Escherichia coli was grown in Luria-Bertani medium and plasmid DNA was extracted using the NucleoSpin Plasmid Quick Pure kit (Macherey-Nagel). Equal concentrations of plasmid DNA from each clone $\left(30 \mathrm{ng}^{-1} \mathrm{l}^{-1}\right)$ were mixed, and different amounts of this mixture (Table 1) were combined with $1 \mu \mathrm{l}$ of DNA extract from 1 environmental sample of surface sea-

Table 1. Contribution (in \%) of DNA from mixed clones and DNA from an environmental sample (March 2003) to total DNA in each PCR product. Numbers from 1 to 12 correspond to samples amplified with primer set $357 \mathrm{fGC}-907 \mathrm{r}$, whereas numbers from $1^{\prime}$ to 12 ' refer to primer set $357 \mathrm{fGC}$ 907rM. 16S rRNA gene copy number has also been roughly estimated. Grey shading indicates the lowest target concentration where the 2 clones appear in the DGGE gel (see Fig. 1) for each primer set

\begin{tabular}{|c|c|c|}
\hline Sample & $\begin{array}{c}\text { \% of DNA from } \\
\text { the added clones } \\
(16 \mathrm{~S} \text { rRNA copy number })^{\mathrm{a}}\end{array}$ & $\begin{array}{c}\% \text { of DNA from environ- } \\
\text { mental sample (16S rRNA } \\
\text { copy number })^{b}\end{array}$ \\
\hline $1,1^{\prime}$ & $\begin{array}{c}0 \\
(0)\end{array}$ & $\begin{array}{c}100 \\
\left(3.7 \times 10^{6}\right)\end{array}$ \\
\hline $2,2^{\prime}$ & $\begin{array}{c}0.01 \\
\left(5.2 \times 10^{5}\right)\end{array}$ & $\begin{array}{c}99.9 \\
\left(3.7 \times 10^{6}\right)\end{array}$ \\
\hline $3,3^{\prime}$ & $\begin{array}{c}0.2 \\
\left(1.0 \times 10^{6}\right)\end{array}$ & $\begin{array}{c}99.8 \\
\left(3.7 \times 10^{6}\right)\end{array}$ \\
\hline $4,4^{\prime}$ & $\begin{array}{c}0.5 \\
\left(2.6 \times 10^{6}\right)\end{array}$ & $\begin{array}{c}99.5 \\
\left(3.7 \times 10^{6}\right)\end{array}$ \\
\hline $5,5^{\prime}$ & $\begin{array}{c}1 \\
\left(5.2 \times 10^{6}\right)\end{array}$ & $\begin{array}{c}99.0 \\
\left(3.7 \times 10^{6}\right)\end{array}$ \\
\hline $6,6^{\prime}$ & $\begin{array}{c}9.1 \\
\left(5.2 \times 10^{7}\right)\end{array}$ & $\begin{array}{c}90.9 \\
\left(3.7 \times 10^{6}\right)\end{array}$ \\
\hline $7,7^{\prime}$ & $\begin{array}{c}16.7 \\
\left(1.0 \times 10^{8}\right)\end{array}$ & $\begin{array}{c}83.3 \\
\left(3.7 \times 10^{6}\right)\end{array}$ \\
\hline $8,8^{\prime}$ & $\begin{array}{c}33.3 \\
\left(2.6 \times 10^{8}\right)\end{array}$ & $\begin{array}{c}66.7 \\
\left(3.7 \times 10^{6}\right)\end{array}$ \\
\hline $9,9^{\prime}$ & $\begin{array}{c}50 \\
\left(5.2 \times 10^{8}\right)\end{array}$ & $\begin{array}{c}50 \\
\left(3.7 \times 10^{6}\right)\end{array}$ \\
\hline $10,10^{\prime}$ & $\begin{array}{c}90.9 \\
\left(5.2 \times 10^{9}\right)\end{array}$ & $\begin{array}{c}9.1 \\
\left(3.7 \times 10^{6}\right)\end{array}$ \\
\hline $11,11^{\prime}$ & $\begin{array}{c}95.2 \\
\left(1.0 \times 10^{10}\right)\end{array}$ & $\begin{array}{c}4.8 \\
\left(3.7 \times 10^{6}\right)\end{array}$ \\
\hline $12,12^{\prime}$ & $\begin{array}{c}98 \\
\left(2.6 \times 10^{10}\right)\end{array}$ & $\begin{array}{c}2 \\
\left(3.7 \times 10^{6}\right)\end{array}$ \\
\hline \multicolumn{3}{|c|}{$\begin{array}{l}\text { aNumbers calculated taking into consideration a plasmid } \\
\text { plus } 16 \mathrm{~S} \text { rRNA gene size of } 5396 \text { bases } \\
\text { b Based on a mean genome size of } 1600 \mathrm{~kb} \text { (Raes et al. 2007) } \\
\text { and a mean 16S rRNA gene copy number of } 2.1 \text { cell }^{-1} \\
\text { (Moran et al. 2004) }\end{array}$} \\
\hline
\end{tabular}


water from Blanes Bay collected in March 2003 $\left(3 \mathrm{ng} \mathrm{l}^{-1}\right)$. A rough indication of the 16S rRNA gene copy number was determined for the mixture of plasmidic DNA and the environmental sample. For environmental DNA, calculations were done with a mean genome size of $1600 \mathrm{~kb}$ (Raes et al. 2007) and a mean 16S rRNA copy number of 2.1 (Moran et al. 2004). The environmental sample was processed as in Sánchez et al. (2007), and DNA extraction was performed as described by Massana et al. (1997).

PCR-DGGE fingerprinting. PCR was carried out using 2 primer sets separately: $357 \mathrm{f}\left(5^{\prime}-\mathrm{CCT}\right.$ ACG GGA GGC AGC AGC AG-3')-907r (5'-CCG TCA ATT CCT TTR AGT TT-3') and 357f-907rM (5'-CCG TCA ATT CMT TTG AGT TT-3'). Primers 907r and 907rM differ at 2 base positions, and the latter is the most widely used today. Primer $357 \mathrm{f}$ carried a $40 \mathrm{bp} \mathrm{GC}$ clamp on the $5^{\prime}$ end. PCR conditions were the same for both primer sets and have been described previously (Sánchez et al. 2007).

The PCR mixtures contained $1 \mu \mathrm{l}$ template DNA, each deoxynucleoside triphosphate at a concentration of $200 \mu \mathrm{M}, 1.5 \mathrm{mM} \mathrm{MgCl}_{2}$, each primer at a concentration of $0.5 \mu \mathrm{M}, 1.25 \mathrm{U}$ Taq DNA polymerase (Invitrogen), and PCR buffer supplied by the manufacturer. Bovine Serum Albumin (BSA) at a final concentration of $600 \mu \mathrm{g} \mathrm{ml}^{-1}$ was added to minimize the inhibitory effect of humic substances. The volume of reactions was $50 \mu \mathrm{l}$. PCR products were verified and quantified by agarose gel electrophoresis with a low DNA mass ladder standard (Invitrogen).

The PCR products obtained from these mixtures were run in a DGGE gel at $60^{\circ} \mathrm{C}$ with a CBS Scientific system as previously described by Muyzer et al. (1998) using a 40 to $80 \%$ gradient ( $6 \%$ acrylamide) at $100 \mathrm{~V}$ $(17 \mathrm{~h})$. The gel was stained with SybrGold (Molecular Probes) for $45 \mathrm{~min}$, rinsed with $1 \times$ Tris-acetate-EDTA buffer, removed from the glass plate to a UV-transparent gel scoop, and visualized with UV in a Chemi Doc system (Bio-Rad). DGGE images were analyzed using the Quantity One software (Bio-Rad) in order to detect the different bands present in the gels.

\section{RESULTS AND DISCUSSION}

DGGE gels (Fig. 1) indicated that both sets of primers could amplify the SAR11 clones when alone in the DNA template. When mixed with environmental DNA (samples $1 / 1^{\prime}$ to $12 / 12^{\prime}$ ), the 2 bands corresponding to these clones appeared at lower target concentrations in the gel where primer pair $357 \mathrm{fGC}-907 \mathrm{rM}$ was used (40 times less of the mix of plasmidic DNA was needed for their detection, as indicated with arrows in Fig. 1). We estimated the 16S rRNA gene copy number
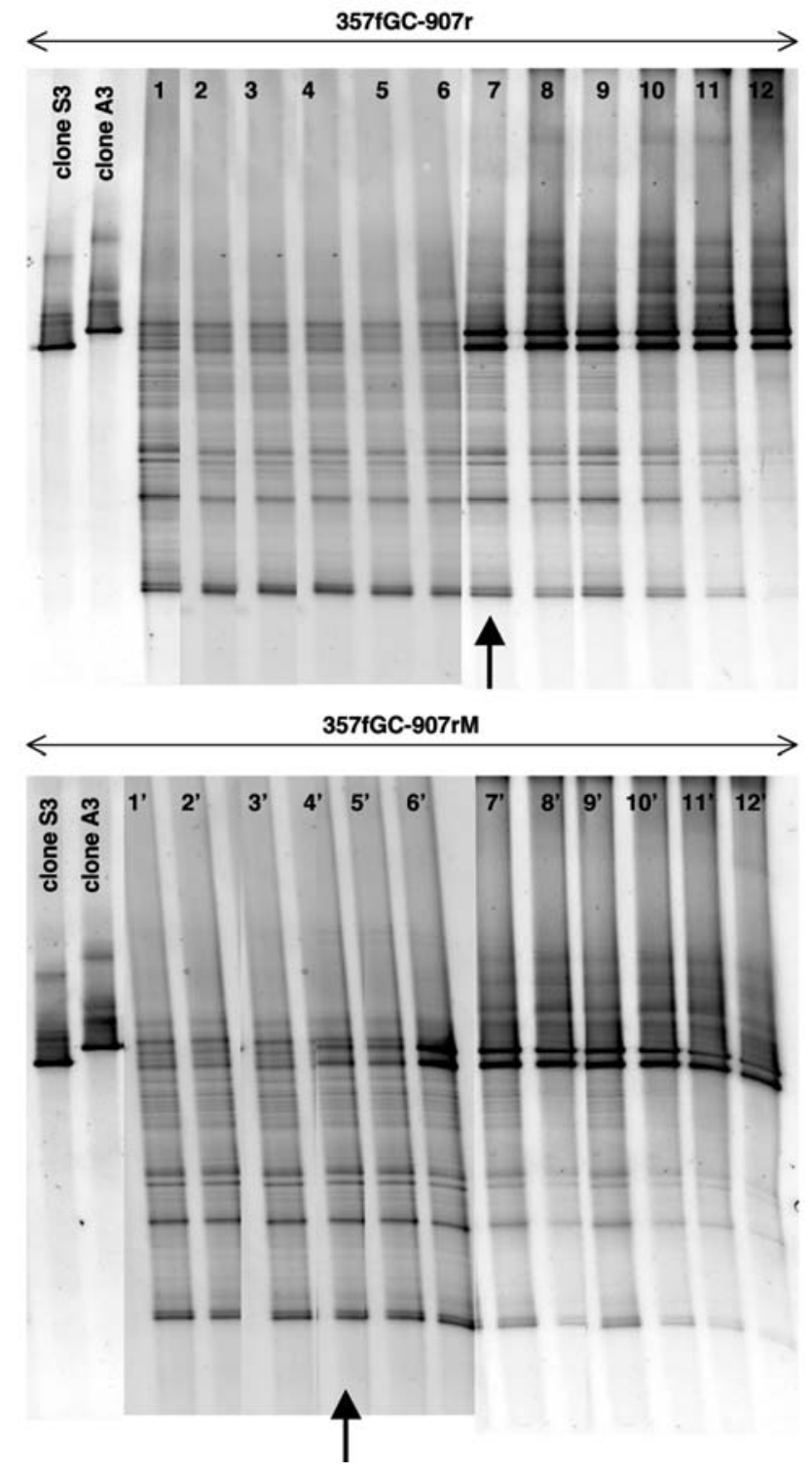

Fig. 1. DGGE fingerprints obtained with 2 different primer sets showing the influence of primer mismatching on SAR11 detection. Samples 1 to 12 correspond to PCR products obtained by combining different increasing amounts of plasmidic DNA (mix of clones S3 + A3) and DNA from a Blanes Bay sample (see Table 1). Arrows at the bottom of each gel indicate the lowest amount of plasmidic DNA mix where the 2 clones appear

for the plasmidic mixture and the environmental sample (Table 1). Based on this estimation, primer set 357fGC-907rM significantly amplified the SAR11 clones when the gene copy number was the same order of magnitude as the gene copy number of the environmental sample (corresponding to sample 4 '), in contrast to primer set $357 \mathrm{fGC}-907 \mathrm{r}$, which clearly amplified both clones when the gene copy number was 2 orders of magnitude above that of the environmental sample (sample 7). This indicates that a larger number 
of copies would be needed in order to significantly detect SAR11 in this last case (around $41 \%$ of the total copy number in the case of primer set $357 \mathrm{fGC}-907 \mathrm{rM}$, and $96 \%$ for primer set $357 f G C-907 r$ r).

Besides the clear and expected effect of primer mismatches, we hypothesized that another reason for the discrepancy between DGGE and other molecular techniques could be the presence of multiple low-abundance microdiverse phylotypes within the SAR11 group in the Blanes Bay Microbial Observatory.

The concept of microdiversity, i.e. the genetic diversity within species-like phylogenetic groups, has been recently addressed by different authors. It has been well documented for marine and freshwater habitats, for specific populations such as sulfate-reducing bacteria and populations of Vibrio and Polynucleobacter (Acinas et al. 2004, Klepac-Ceraj et al. 2004, Hahn \& Pöckl 2005, Zo et al. 2008). However, and as far as we know, little research has been done concerning microdiversity of the SAR11 group. Acinas et al. (2004) studied fine-scale phylogenetic relationships in a bacterioplankton sample and constructed phylogenetic trees with the relationships between SAR11 clusters; they observed that the number of operational taxonomic units (OTUs) plotted against changing degrees of cutoffs decreased significantly from 100 to $99 \%$ sequence similarity, and the SAR11 group formed the most sequence-rich microdiverse clusters. Other studies, such as the one of García-Martínez \& RodríguezValera (2000), showed a very large group of SAR11 clones with high within-cluster similarity $(<1 \%$ of nucleotide differences).

In order to estimate the microdiversity of the SAR11 group present in Blanes Bay, we analyzed 20 randomly selected SAR11 clones obtained from different libraries from this environment. Similarity clustering showed a remarkable decline in the number of OTUs as cluster cut-off values were decreased from 98 to $91 \%$ (Fig. 2). In stark contrast, the number of OTUs greatly exceeded this decline for values above $98 \%$, which suggests decreased removal of diversity within microdiverse clusters. For the sake of comparison, 20 phylotypes of the same clone libraries corresponding to the Roseobacter clade were also analyzed. Roseobacter, in contrast to SAR11, does appear frequently in DGGE gels of Blanes Bay, despite the fact that it is much less abundant than SAR11, as detected by clone libraries and CARD-FISH (Alonso-Sáez et al. 2007). For this group, there was a gradual and continuous decline in the number of OTUs between cut-off values of 100 and $82 \%$ of cluster similarity (Fig. 2). Therefore, in the case of SAR11, $50 \%$ of the ribotypes fall into discrete clusters containing $<2 \%$ of divergence (between 100 and $98 \%$ similarity), while for Roseobacter this value was between 100 and $93 \%$.

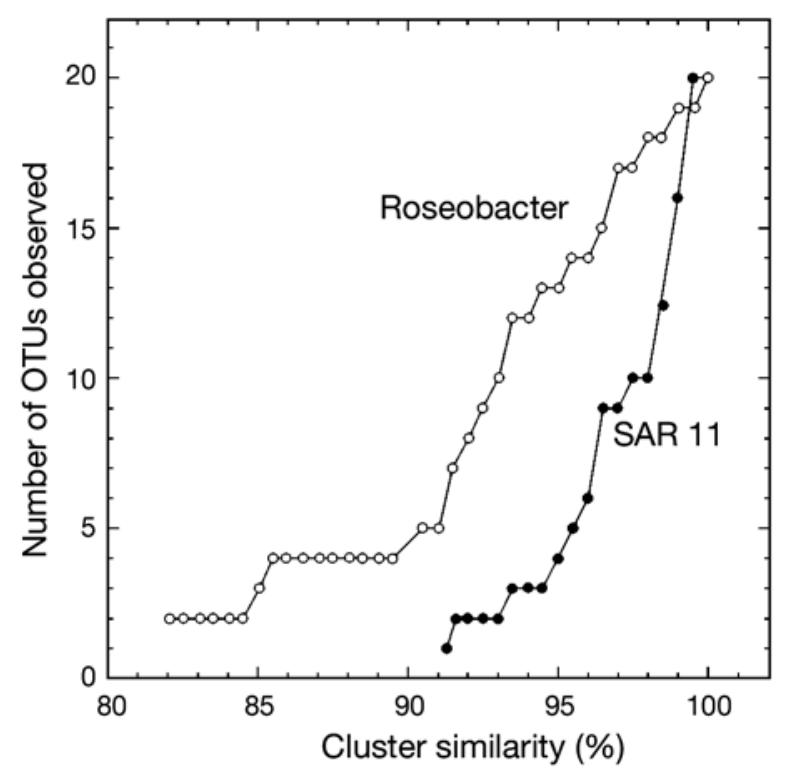

Fig. 2. Microdiversity analysis from SAR11 and Roseobacter sequences obtained from different clone libraries from the Blanes Bay Microbial Observatory. Number of operational taxonomic units (OTUs) is plotted against changing degrees of cut-offs in $0.5 \%$ increments for grouping of sequences into similarity clusters

Thus, according to these results, microdiversity seems to be a feasible explanation for the frequent absence of significant bands of SAR11 in DGGE gels.

Apart from the problems in DGGE analyses caused by faint bands due to microdiversity and primer specificity, an additional problem was the position of SAR11 bands in DGGE gels. When several SAR11 clones from Blanes Bay clone libraries were run in a DGGE gel, it was apparent that they migrated within quite a narrow region of the gel, which hampered the attempts to obtain clean sequences from these bands (Alonso-Sáez et al. 2007).

Kan et al. (2006) also used bacterial seeding experiments to determine the detection thresholds for PCRDGGE, demonstrating that concentrations ranging from $2.5 \times 10^{3}$ to $1 \times 10^{4}$ cells ml $^{-1}$ ( 0.1 to $0.4 \%$ of total cell counts, depending on the rRNA operon copy number considered) were below the detection limit, and consequently these bacteria would be absent from a DGGE gel. If we assume that all the different SAR11 clones obtained from diverse clone libraries of Blanes Bay made the same contribution to total abundance, and taking into account from CARD-FISH data the overall contribution of SAR11 to total DAPI counts in every clone library (Alonso-Sáez et al. 2007), we can estimate a concentration range of $1.6 \times 10^{3}$ to $8.2 \times 10^{3}$ cells $\mathrm{ml}^{-1}$ for each SAR11 phylotype. These values are below the detection limit of DGGE proposed by Kan et al. (2006). 
Table 2. Presence of SAR11 in some studies in which the marine bacterioplankton community has been analyzed by DGGE. CARD-FISH: catalyzed reporter deposition-fluorescence in situ hybridization

\begin{tabular}{|lccc|}
\hline Sampling site & $\begin{array}{c}\text { Detection of SAR11 } \\
\text { by DGGE }\end{array}$ & $\begin{array}{c}\text { Other molecular methods } \\
\text { used in the work/ } \\
\text { detection of SAR11 }\end{array}$ & Source \\
\hline Arabian Sea & + & Quantitative PCR / + & Fiemann et al. (1999) \\
Southern California & - & Clone libraries / + & Simu \& Hagström (2001) \\
California Bight, & \pm (depending & & Bano \& Hollibaugh (2002) \\
Skagerak, Baltic Sea & on the site) & & Schauer et al. (2003) \\
Arctic Ocean & + & Selje \& Simon (2003) \\
NW Mediterranean & - & & Crump et al. (2004) \\
Weser estuary & + & Clone libraries / + & Sala et al. (2005) \\
Estuarine waters & - & CARD-FISH / + & Kan et al. (2006) \\
(Massachusetts) & - & Alonso-Sáez et al. (2007) \\
NW Mediterranean & - & Clone libraries / + & Celussi \& Cataletto (2007) \\
Baltimore inner harbor & - & & Crump et al. (2007) \\
NW Mediterranean & - & & Sapp et al. (2007) \\
Gulf of Trieste & - & & \\
Chesapeake Bay & & & \\
North Sea & & &
\end{tabular}

The experiments carried out here using 2 clones of SAR11 as internal standards confirmed, first, that primer $907 \mathrm{rM}$ is more suitable for SAR11 amplification than primer $907 \mathrm{r}$ and, second, that there are no specific biases against SAR11 that could prevent their appearance in the DGGE gels. Instead, large evenness of closely related, equally abundant microdiverse organisms could generate several separate bands that are too faint for further sequencing. SAR11 was indeed present in the environmental sample used as a control, based on CARD-FISH and clone libraries (Alonso-Sáez et al. 2007). In a previous study, Schauer et al. (2003) also used the primer pairs 357fGC-907r and 357fGC$907 \mathrm{rM}$ to characterize the diversity of this microbial assemblage. They obtained almost identical fingerprints with both primer sets, but they could not retrieve SAR11 phylotypes from the DGGE gels, probably due to the presence of faint bands that were not intense enough for sequencing.

Nevertheless, SAR11 bands have been detected from marine samples in some studies where DGGE has been used as a fingerprinting technique (Table 2), indicating that not all representatives of this particular phylogenetic group are always rare and below the detection limits of the DGGE technique. In view of our results, a possible explanation could be that microdiversity was lower in these cases.

In conclusion, although DGGE constitutes a useful fingerprinting method, care must be taken with the groups showing significant microdiversity, and primer specificity has to be taken into account. The consequences of missing a dominant group are detrimental to the description of the role of specific bacterial groups in marine environments.
Acknowledgements. This work was supported by the Spanish projects ESTRAMAR (CTM2004-12631/MAR), GENM 4 MAR (CTM2004-02586/MAR), TRAGUA (CSD2006-00044), TEC2006-13109-C03-02/MIC, PET2008-0165-02, MODIVUS (CTM2005-04975/ MAR), and EU NoEs MARBEF and Marine Genomics Europe. We thank I. Forn for help with field sampling and lab support, and S. G. Acinas for help with the microdiversity analyses.

\section{LITERATURE CITED}

Acinas SG, Klepac-Ceraj V, Hunt DE, Pharino C, Ceraj I, Distel DL, Polz MF (2004) Fine-scale phylogenetic architecture of a complex bacterial community. Nature 430: $551-554$

Alonso-Sáez L, Gasol JM (2007) Seasonal variations in the contributions of different bacterial groups to the uptake of low-molecular-weight compounds in northwestern Mediterranean coastal waters. Appl Environ Microbiol 73: 3528-3535

Alonso-Sáez L, Balagué V, Sà EL, Sánchez O and others (2007) Seasonality in bacterial diversity in north-west Mediterranean coastal waters: assessment through clone libraries, fingerprinting and FISH. FEMS Microbiol Ecol 60:98-112

Alonso-Sáez L, Sánchez O, Gasol JM, Balagué V, Pedrós-Alio C (2008) Winter-to-summer changes in the composition and single-cell activity of near-surface Arctic prokaryotes. Environ Microbiol 10:2444-2454

Bano N, Hollibaugh JT (2002) Phylogenetic composition of bacterioplankton assemblages from the Arctic Ocean. Appl Environ Microbiol 68:505-518

Casamayor EO, Schäfer H, Bañeras L, Pedrós-Alió C, Muyzer G (2000) Identification and spatio-temporal differences between microbial assemblages from two neighboring sulfurous lakes: comparison by microscopy and denaturing gradient gel electrophoresis. Appl Environ Microbiol 66:499-508

Castle D, Kirchman DL (2004) Composition of estuarine bacterial communities assessed by denaturing gradient gel 
electrophoresis and fluorescence in situ hybridization. Limnol Oceanogr Methods 2:303-314

Celussi M, Cataletto B (2007) Annual dynamics of bacterioplankton assemblages in the Gulf of Trieste (Northern Adriatic Sea). Gene 406:113-123

> Crump BC, Hopkinson CS, Sogin ML, Hobbie JE (2004) Microbial biogeography along an estuarine salinity gradient: combined influences of bacterial growth and residence time. Appl Environ Microbiol 70:1494-1505

Crump BC, Peranteau C, Beckingham B, Cornwell JC (2007) Respiratory succession and community succession of bacterioplankton in seasonally anoxic estuarine waters. Appl Environ Microbiol 73:6802-6810

Fandino LB, Riemann L, Stewart GF, Long RA, Azam F (2001) Variations in bacterial community structure during a dinoflagellate bloom analyzed by DGGE and 16S rDNA sequencing. Aquat Microb Ecol 23:119-130

García-Martínez J, Rodríguez-Valera F (2000) Microdiversity of uncultured marine prokaryotes: the SAR11 cluster and the marine Archaea of Group I. Mol Ecol 9:935-948

Hahn MW, Pöckl M (2005) Ecotypes of planktonic Actinobacteria with identical 16S rRNA genes adapted to thermal niches in temperate, subtropical, and tropical freshwater habitats. Appl Environ Microbiol 71:766-773

Kan J, Wang K, Chen F (2006) Temporal variation and detection limit of an estuarine bacterioplankton community analyzed by denaturing gradient gel electrophoresis (DGGE). Aquat Microb Ecol 42:7-18

Kisand V, Wikner J (2003) Combining culture-dependent and -independent methodologies for estimation of richness of estuarine bacterioplankton consuming riverine dissolved organic matter. Appl Environ Microbiol 69:3607-3616

Klepac-Ceraj V, Bahr M, Crump BC, Teske AP, Hobbie JE, Polz MF (2004) High overall diversity and dominance of microdiverse relationships in salt marsh sulphate-reducing bacteria. Environ Microbiol 6:686-698

Klepac-Ceraj V, Ceraj I, Polz MF (2006) Clusterer: extendable java application for sequence grouping and cluster analyses. Online J Bioinform 7:15-21

Kong YH, Beer M, Seviour RJ, Lindrea KC, Rees GN (2001) Structure and functional analysis of the microbial community in an aerobic:anaerobic sequencing batch reactor (SBR) with no phosphorus removal. Syst Appl Microbiol 24:597-609

Massana R, Murray AE, Preston CM, DeLong EF (1997) Vertical distribution and phylogenetic characterization of marine planktonic Archaea in the Santa Barbara Channel. Appl Environ Microbiol 63:50-56

Moran MA, Buchan A, González JM, Heidelberg JF and others (2004) Genome sequence of Silicibacter pomeroyi reveals adaptations to the marine environment. Nature 432:910-913

Morris RM, Rappé MS, Connon SA, Vergin KL, Siebold WA, Carlson CA, Giovannoni SJ (2002) SAR11 clade dominates

Editorial responsibility: Dittmar Hahn,

San Marcos, Texas, USA ocean surface bacterioplankton communities. Nature 420 : $806-810$

Muyzer G, Brinkhoff T, Nübel U, Santegoeds C, Schäfer H, Wawer C (1998) Denaturing gradient gel electrophoresis (DGGE) in microbial ecology. In: Akkermans ADL, van Elsas JD, de Bruijn FJ (eds) Molecular microbial ecology manual. Kluwer Academic Publishers, Dordrecht, p 3.4.4/ $1-27$

Pinhassi J, Sala MM, Havskum H, Peters F, Guadayol Ò, Malits A, Marrasé C (2004) Changes in bacterioplankton composition under different phytoplankton regimens. Appl Environ Microbiol 70:6753-6766

> Raes J, Korbel JO, Lercher MJ, von Mering C, Bork P (2007) Prediction of effective genome size in metagenomic samples. Genome Biol 8:R10

> Riemann L, Steward GF, Fandino LB, Campbell L, Landry MR, Azam F (1999) Bacterial community composition during two consecutive NE Monsoon periods in the Arabian Sea studied by denaturing gradient gel electrophoresis (DGGE) of rRNA genes. Deep-Sea Res II 46:1791-1811

Sala MM, Balagué V, Pedrós-Alió C, Massana R and others (2005) Phylogenetic and functional diversity of bacterioplankton during Alexandrium spp. blooms. FEMS Microbiol Ecol 54:257-267

- Sánchez O, Gasol JM, Massana R, Mas J, Pedrós-Alió C (2007) Comparison of different denaturing gradient gel electrophoresis primer sets for the study of marine bacterioplankton communities. Appl Environ Microbiol 73: 5962-5967

Sapp M, Wichels A, Wiltshire KH, Gerdts G (2007) Bacterial community dynamics during the winter-spring transition in the North Sea. FEMS Microbiol Ecol 59:622-637

Schauer M, Balagué V, Pedrós-Alió C, Massana R (2003) Seasonal changes in the taxonomic composition of bacterioplankton in a coastal oligotrophic system. Aquat Microb Ecol 31:163-174

Selje N, Simon M (2003) Composition and dynamics of particle-associated and free-living bacterial communities in the Weser estuary, Germany. Aquat Microb Ecol 30:221-237

Simu K, Hagström A (2001) Universal presence of bacteria, Sargasso Sea clones (SAR11) in the Baltic Sea. Poster presented at the Baltic Sea Science Congress 2001, Stockholm

Thompson JD, Gibson TJ, Plewniak F, Jeanmougin F, Higgins DG (1997) The CLUSTAL_X windows interface: flexible strategies for multiple sequence alignment aided by quality analysis tools. Nucleic Acids Res 25:4876-4882

Torsvik V, Daae FL, Sandaa RA, Ovreås L (1998) Novel techniques for analysing microbial diversity in natural and perturbed environments. J Biotechnol 64(1):53-62

Zo YG, Chokesajjawatee N, Arakawa E, Watanabe H, Huq A, Colwell RR (2008) Covariability of Vibrio cholerae microdiversity and environmental parameters. Appl Environ Microbiol 74:2915-2920

Submitted: July 15, 2008; Accepted: November 19, 2008 Proofs received from author(s): February 13, 2009 